\title{
Non-Therapeutic Circumcision of Boys: Medical, Sociocultural and Ethical View
}

\section{Erkek Çocuklarının Sünneti: Tıbbi, Sosyokültürel ve Etik Açıdan Değerlendirilmesi}

Ŏguz Özler ${ }^{1}$

\footnotetext{
Koç University, School of Medicine, Department of Pediatrics, Istanbul, Turkey
}

ORCID: O.Ö. 0000-0002-6886-9875

Corresponding author/Sorumlu yazar: Oğuz Özler,

Koç University, Faculty of Medicine, Department of Pediatrics, Istanbul, Turkey

E-mail: oozler@ku.edu.tr

Submitted/Geliș tarihi: 11.05.2021

First Revision Received/İlk revizyon: 18.01.2021 Last Revision Received/Son Revizyon: 04.03.2021 Accepted/Kabul Tarihi: 28.03.2021

Citation/Atıf: Ozler O. Non-therapeutic circumcision of boys: medical, sociocultural and ethical view. Sağlık Bilimlerinde İleri Araştırmalar Dergisi 2021; 4(3): 125-129. https://doi.org/10.26650/JARHS2021-735870

\begin{abstract}
There is no medical or ethical consensus over the necessity and the ethical statue of nontherapeutic circumcision of boys. From the medical aspect, there are some potential medical benefits like decreased UTI contracture and Human Immunodeficiency Virus (HIV). transmission rates. However, it is an intervention to the child's bodily integrity and has some surgical complications like bleeding, pain, postoperative infection and inadequate skin removal. Complication rates are low when the surgery is done according to medical standards. When considering the ethical aspects of circumcision, the most important question to be asked is 'What is the best interest of the child?' In order to answer this question, all medical, cultural and psychosocial aspects of the circumcision need to be evaluated. It is an important part of sociocultural life especially in Islamic and Jewish societies. Therefore, it is necessary for the child to be integrated to society and to socialize in that environment. Since it is not a fact whether the medical benefits outweigh the risk or vice versa, the right of the parents to raise a child according to their sociocultural and religious beliefs and the right of the child to be a part of the society should not be eliminated.
\end{abstract}

Keywords: Male Circumcision, Medical Ethics, Social Integration

ÖZ

Erkek çocuklarında terapötik olmayan sünnet uygulamasının gerekliliği konusunda tıbbi ve etik açıdan bir fikir birliğine varılmış değildir. Tıbbi olarak, idrar yolu enfeksiyon sıklığını ve HIV bulaş ihtimalini azaltması gibi potansiyel faydaları mevcuttur. Öte yandan bu işlem çocuğun vücut bütünlüğünü bozmaktadır ve kanama, ağrı, operasyon sonrası enfeksiyon ve yetersiz miktarda cildin alınması gibi komplikasyonları da mevcuttur. Ancak ameliyat tıbbi standartlara uygun yapılırsa komplikasyon ihtimali düşüktür. Sünnetin etik boyutunu tartışırken sorulması gereken en önemli soru 'Çocuğa en faydalı olan nedir?' sorusudur. Bu soruyu cevaplandırabilmek için sünnetin tıbbi, kültürel ve psikolojik boyutlarının tamamı ele alınmalıdır. Çünkü erkek çocuklarının sünneti özellikle Müslüman ve Yahudi toplumlarda sosyo-kültürel hayatın önemli bir parçasıdır. Bu yüzden çocuğun topluma entegre olup o çevrede sosyalleşmesi gerekir. Tıbbi faydalarının zararlarına oranla üstün veya düşük olup olmadığı henüz bilimsel bir gerçek halini almadığı için, ailelerin çocuklarını kendi sosyokültürel ve dini inanışlarına göre yetiştirme hakkı ve çocukların da bulunduğu toplumun sosyal anlamda bir üyesi olması hakkı ellerinden alınmamalıdır.

Anahtar Kelimeler: Erkek Sünneti, Tibbi Etik, Sosyal Entegrasyon 


\section{INTRODUCTION}

After the decision of the Cologne district court that the non-therapeutic circumcision (NCT) is a bodily assault (1), this topic became very popular and controversial among medical, social, and ethical environments. This controversy originated from the unclear determination of the necessity of the procedure in terms of medical and social indications. From a medical viewpoint, it is a surgical intervention that is done without any pathology. Even if it is a minor intervention it has some surgical risks. The most significant complication is bleeding $(2,3,4)$. On the other hand, NCT has some potential medical benefits when applied prophylactically. Decreased urinary tract infections and decreased HIV transmission are the most important ones (3). From the sociocultural and religious standpoint, it is an important ritual of the Islamic and Jewish belief. Especially in Judaism, it is seen as an entrance into the religion and the society (5). It is also such a sociocultural norm in Islamic societies that even boys of many non-believer families are circumcised (6). Since it is a surgical intervention that creates irreversible loss of tissue and also an important standpoint in the Islamic and Jewish belief and social life, a multidisciplinary approach is necessary when assessing the ethical aspects of the non-therapeutic circumcision of boys.

\section{CLINICAL AND RESEARCH EF- FETCS ISLAMIC CONSIDERATION OF CIRCUMCISION}

Male circumcision has a long historical value. Gollaher says that this ritual started in 5000 B.C (5). In Islamic resources, the most important figure associated with male circumcision is Abraham. It is said that he circumcised himself following the order of the God (6). Although there is no definite saying about circumcision in the holy book of Islam, in the Quran, there is a surah saying that 'God says the truth and Abraham follows the rules of the God. So, follow Abraham's religious beliefs and behaviors.'Therefore, Islam professors interpret it as an encouragement for circumcision. It is also said that Muhammad was a circumcised man too. Also, there are many hadiths said by Muhammad about circumcision. It is said that he suggested circumcision to Muslims and he also circumcised his grandsons (6). Since this ritual is not mentioned in the Quran but in Mohammad's hadiths, there are some controversies about its interpretation. While some Islamic doctrines interpret male circumcision as obligatory, some of them mention it as the sunna. There is also no consensus over the timing of the circumcision. Some doctrines arguing that it should be done at day seven like grandsons of Mohammad. Some others suggest an early circumcision before the puberty (7).

\section{SOCIOCULTURAL ROLE OF CIR- CUMCISION}

Male circumcision has a long history in Islamic societies. Although it is not seen as a milestone to be a Muslim, it has a significant importance in the sociocultural life as a traditional ritual such that, it is carried out as a celebration. For instance, all family members, neighbors, and friends are invited to the ritual. Some kind of food is served for them and they also give some gifts or money to the circumcised boy. The boy wears special clothing. Some gifts are given to his friends and a city tour is organized before the operation. Since it is seen as such an important consideration not only for Muslim individuals but also the whole society, even some secular or non-believer families circumcise their boys. Therefore, there is a very high circumcision rate in the societies in which Islam is dominant as a religion. This ratio may reach up to $90-100 \%$ (6).

\section{MEDICAL ASPECT}

The controversy on the topic is mainly based on the medical aspect. On one side, it is a surgical intervention and like any other surgical procedure, there are some complications and potential harm to the child. Moreover, making this intervention in the absence of any relevant pathology makes it more debatable. On the other side of the medical aspect, it is shown that there are some potential benefits both in the childhood period and in the adult life like decreased rates of urinary tract infection and HIV trans- 
mission (3). Although it is crucial to assess the benefits and harms in terms of medical, social, cultural and psychological aspects when determining 'the best interest of the child', it is very hard to compare a medical benefit or harm with a cultural one. Therefore, it would be more appropriate to evaluate the best interest of the child separately first and then try to make a conclusion.

\section{Harms}

Although there are many controversies surrounding circumcision, it is clear that it causes an irreversible tissue loss. However, there is ongoing debate about the potential loss of function from the procedure. It is said that the foreskin provides an immunological defense barrier (8). On the other hand, it has been shown that circumcision decreases urinary tract infection rates (3). Some studies also show that there are some orgasm difficulties and erectile problems in circumcised man (9). Although some others show there is no significant difference in sexual function (10). Complication rates vary according to many determinants. For instance, associated comorbidities like bleeding diathesis, anatomic abnormalities, patient age, and surgical technique. Krill classifies the complications as early ones being 'bleeding, postoperative infection, pain and inadequate skin removal' and late ones as 'epidermal inclusion cysts, suture sinus tracts, chordee, inadequate skin removal resulting in redundant foreskin, penile adhesions, phimosis, buried penis, urethrocutaneous fistulae, meatitis, and meatal stenosis.' He also states that early complications are mostly minor and quite treatable unless the child has associated anomalies. Furthermore, late complications are frequently treated in outpatient clinics (2). The most significant complication is bleeding with a $1 \%$ incidence (4).In most of the cases, bleeding can be stopped by direct pressure or silver nitrate cautery. In a retrospective study, 48 circumcised boys with varying degree of coagulopathies were investigated and 11 bleeding complications were observed. None of them were severe complications that require $\mathrm{RBC}$ transfusion (11).

\section{Benefits}

AAP declared a policy statement in 2012 saying that newborn male circumcision has potential medical benefits. However, the data is not sufficient to suggest routine neonatal circumcision. It is said that medical benefits should be assessed with other potential benefits and risks and parents should give the decision about the best interest of the child (12).

AAP also reviewed the literature comprehensively about the association between circumcision status and UTI contracture. Many data show that there is a significantly decreased risk in circumcised boys. Collectively, it is estimated that rates of UTI contracture in uncircumcised boys is 7 times higher. Its impact on reducing UTIs is greatest in the first year of life (13). Although penile cancer has a relatively low incidence, an at least 3-fold increased risk of penile cancer has also been shown in uncircumcised men $(14,15)$. Another important benefit is the decreased rate of acquiring sexually transmitted infections especially HIV. Three randomized controlled studies in Sub-Saharan Africa showed a significant decrease of HIV transmission in circumcised man (16). Also, there are several studies from the USA since the beginning of the HIV pandemic showing the decreased acquisition of HIV in circumcised man (3). Circumcision also prevents phimosis, paraphimosis and balanoposthitis and decreases the rate of meatitis (17).

\section{ETHICAL ASPECT}

Circumcision is not only a surgical intervention but also a social, cultural, and psychological part of daily life especially in Islamic societies. Since it is mostly performed before the child is autonomous, it puts forward the question 'What is the best interest of the child?' and who should decide it. Therefore, the multiple aspects of circumcision should be assessed carefully and decided as a whole.

\section{Opponents}

Many opposing views about the NTC of boys gather around the open future principle of Feinberg and Davis. According to this principle, children have special rights that they cannot yet exercise but will be able to in adulthood. Therefore, parents should not attempt to foreclose the future options of their 
child (18). Another ethical principle applying for circumcision is autonomy. According to opposing views, since the child is not autonomous, the procedure should be delayed until the adulthood (18). Furthermore, circumcision causes an irreversible loss of tissue and creates damage to the bodily integrity of the child. This intervention is made without any medical indication. Like any other surgical intervention, it has some complications and it is against the principle of non-maleficence. Even if circumcision has some potential benefits to reduce HIV transmission and penile cancer incidence, these benefits become applicable when the child is competent. Another idea is that the physician's primary concern should be the patient themself not the parents. Circumcision is the demand of the parents instead of the child himself. Brady states that most parents circumcise their boys in order for their child to look like their father (19). Even if religious liberty is an important right to consider, creating a permanent body marking in a child whose future religious choice is not evident should not be assessed as liberty (18).

\section{Supporters}

Many views supporting circumcision suggest that even if circumcision creates an irreversible tissue loss, there is no functional loss or serious adverse effects when made accordingly with surgical standards (20). Additionally, circumcision has some potential benefits to the child and the society considering decreased HIV transmission (16). Since the protective effect of circumcision for UTI is greatest at the first year of life, delaying the procedure decreases the benefit that the child can get, so that, circumcision matches the ethical principle of beneficence. Other than the medical harms and benefits, there are important social and cultural considerations. First, parents have the right to raise a child according to their social, cultural and religious beliefs. Since the child is growing up with his family and socializes within his parent's environment, it is in his interest to live in harmony with their cultural and social norms. By preventing circumcision, we would cause the exclusion of the child from the society and therefore take the right of socialization from him. Furthermore, prevention of circumcision makes parents look for illegal ways of doing it. It might create health tourism to places where it is legal. However, such a situation makes it difficult to keep the medical standards for the child's best interest, so that it causes potential harm instead of benefit for the child (5).

\section{CONCLUSION}

While considering a decision over a child, the most important determinant is the principle of 'the best interest of the child.' In the example of circumcision of boys, two arguments come across and need to be assessed carefully: The bodily integrity of the child and right to socialize. Although circumcision is a surgical intervention over the child's body and creates a tissue loss, there is no functional organ loss. Also, complication rates are low when made according to medical standards. On the other hand, the best interest principle includes not only the medical aspect but also social, cultural, and psychological sides. All the factors affect the life of the child as a whole. Being a part of a society and socializing in that environment is needed for mental health and development. Therefore, it is one of the basic rights of human beings. By preventing circumcision, these rights are taken from the child especially in the societies where circumcision has an important role as a sociocultural norm. Moreover, circumcision has important potential medical benefits, so that it would be unethical to prevent the parents from making the decision of what is in the best interest of the child. As a result, all non-biased medical information about circumcision should be given to parents, so they can determine the best interest of the child by considering all the medical, social, cultural, and psychological aspects.

Peer Review: Externally peer-reviewed.

Hakem Değerlendirmesi: Dış bağımsız.

Author Contributions: Conception/Design of Study- O.Ö.; Data Acquisition- O.Ö.; Data Analysis/ Interpretation- O.Ö.; Drafting Manuscript- O.Ö.; Critical Revision of Manuscript- O.Ö.; Final Approval and Accountability- O.Ö.

Çalışma Konsepti/Tasarım- O.Ö.; Veri Toplama- 
O.Ö.; Veri Analizi/Yorumlama- O.Ö.; Yazı Taslağ1O.Ö.; İçeriğin Eleştirel İncelemesi- O.Ö.; Son Onay ve Sorumluluk- O.Ö.

Conflict of Interest: Author declared no conflict of interest.

Çıkar Çatışması: Yazar çıkar çatışması beyan etmemişlerdir

Financial Disclosure: Author declared no financial support.

Finansal Destek: Yazar finansal destek beyan etmemişlerdir.

Acknowledgement: Thanks to Dr. Elif Vatanoglu for her precious help and supervision.

Teșekkür: Eleştirilerinden dolayı Doç. Dr. Elif Vatanoğlu'na çok teşekkür ederim.

\section{REFERENCES}

1. Merkel R, Putzke H. After Cologne: male circumcision and the law. Parental right, religious liberty or criminal assault? J Med Ethics 2013;39(7).:444-9.

2. Krill AJ, Palmer LS, Palmer JS. Complications of circumcision. Scientific World Journal 2011;11(2):2458-68.

3. Brady MT. Newborn Male Circumcision with Parental Consent, as Stated in the AAP Circumcision Policy Statement, Is Both Legal and Ethical. J Law Med Ethics 2016;44(2):25662.

4. Weiss HA, Larke N, Halperin D, Schenker I. Complications of circumcision in male neonates, infants and children: a systematic review. BMC Urol 2010;16(10):2.

5. Jones DA. Infant Male Circumcision: A Catholic Theological and Bioethical Analysis. Linacre Q 2018;85(1):49-62.

6. İlkılıç İ. Erkek çocuk sünnetinin etik açıdan değerlendirilmesi (Ethical evaluation of circumcision of boys).. Türkiye Klinikleri J Urology-Special Topics 2018;11(1): 49-55.

7. El-Beyhaki ABH. Es-Sünenü'l-kübra. 8th ed. Beirut: M. Abdülkādir Atâ; 1994.p.324-6.

8. Svoboda JS. Nontherapeutic Circumcision of Minors as an Ethically Problematic Form of Iatrogenic Injury. AMA J Ethics 2017;19(8):81524.
9. Bronselaer GA, Schober JM, Meyer-Bahlburg HF, T'Sjoen G, Vlietinck R, Hoebeke PB. Male circumcision decreases penile sensitivity as measured in a large cohort. BJU Int 2013;111(5):820-7.

10. Krieger JN, Mehta SD, Bailey RC, AGot K, Ndinya-Achola OJ, Parker C, et al. Adult Male Circumcision: Effects on Sexual Function and Sexual Satisfaction in Kisumu, Kenya. Journal of Sexual Medicine 2008;5(11):2610-22.

11. Rodriguez V, Titapiwatanakun R, Moir C, Schmidt KA, Pruthi RK. To circumcise or not to circumcise? Circumcision in patients with bleeding disorders. Haemophilia 2010;16(2): 272-6.

12. American Academy of Pediatrics Task Force on Circumcision Technical Report. Circumcision policy statement. Pediatrics 2012;130(3):e756-e85.

13. Morris BJ, Wiswell TE. Circumcision and lifetime risk of urinary tract infection: a systematic review and meta-analysis. J Urol 2013;189(6):2118-24.

14. Alkhenizan A, Elabd K. Non-therapeutic infant male circumcision. Evidence, ethics, and international law perspectives. Saudi Med J 2016;37(9):941-7.

15. Hakenberg OW, Dräger DL, Erbersdobler A, Naumann CM, Jünemann KP, Protzel C. The Diagnosis and Treatment of Penile Cancer. Dtsch Arztebl Int 2018;115(39):646-52.

16. Mcmath A. Infant male circumcision and the autonomy of the child: two ethical questions. J Med Ethics 2015;41(8):687-90.

17. Morris BJ, Kennedy SE, Wodak AD, Mindel A, Golovsky D, Schrieber L et al. Early infant male circumcision: Systematic review, risk-benefit analysis, and progress in policy. World J Clin Pediatr 2017;6(1):89-102.

18. Darby RJ. The child's right to an open future: is the principle applicable to non-therapeutic circumcision? J Med Ethics 2013;39(7):463-8.

19. Svoboda JS, Adler PW, Van Howe RS. Circumcision Is Unethical and Unlawful. J Law Med Ethics 2016;44(2):263-82.

20. Tobian AA, Gray RH. The medical benefits of male circumcision. JAMA 2011;306(13):147980. 
